\title{
PENGARUH KOMPETENSI, INDEPENDENSI, KEPATUHAN PADA KODE ETIK DAN MOTIVASI TERHADAP KUALITAS AUDIT APARAT INSPEKTORAT SE-PROPINSI RIAU
}

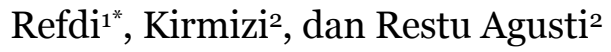 \\ ${ }^{1}$ Program Studi Magister Akuntansi Pasca Sarjana Universitas Riau, Pekanbaru \\ ${ }^{2}$ Fakultas Ekonomi Universitas Riau, Pekanbaru \\ Email : refdi18@yahoo.com
}

\begin{abstract}
Abstrak: Penelitian ini bertujuan menguji pengaruh kompetensi, Independsi, kepatuhan pada kode etik dan motivasi aparat Inspektorat se-Propinsi Riau. Responden dari penelitian ini seluruh auditor pada Inspektorat se-Propinsi Riau. Data yang digunakan penelitian ini diperoleh dari persepsi individu auditor se-Propinsi Riau. Data diperoleh dengan penyebaran kuseioner kepada seluruh auditor sebanyak banyak 148 set kuesioner dari jumlah tersebut kembali 115 set kuesioner dan hanya 113 kuesioner yang dapat diolah. Analisa data menggunakan teknik regresi berganda. Variabel independen dalam penelitian adalah kompetensi $\left(\mathrm{X}_{1}\right)$, independensi $\left(\mathrm{X}_{2}\right)$, kepatuhan pada kode etik $\left(\mathrm{X}_{3}\right)$ dan motivasi $\left(\mathrm{X}_{4}\right)$, sedangkan varibel dependen adalah kualitas audit (Y). Hasil mendapati bahwa kompetensi, independensi, kepatuhan pada kode etik, dan motivasi berpengaruh terhadap kualitas audit. Artinya semakin tinggi kompetentsi, independensi, kepatuan pada kode etik dan motivasi auditor dapat meningkatkan kualitas audit yang diahasilkan. Kompetensi, indepensi, kepatuhan pada kode etik dan motivasi secara bersama-sama berpengaruh terhadap kualitas audit.
\end{abstract}

Kata kunci : Kualitas audit, kompetensi, independensi, kepatuhan pada kode etik, dan motivasi.

\section{PENDAHULUAN}

Akuntabilitas dan transparansi pengelolaan keuangan pemerintah pusat maupun daerah merupakan tujuan penting reformasi akuntansi dan administrasi sektor publik (Badjuri dan Trihapsari, 2004). Audit yang berkualitas sangat dibutuhkan agar pengelolaan keuangan pemerintah dapat berjalan dengan baik, jika kualitas audit rendah dapat menyebabkan terbukanya celah dan ruang bagi organisasi pemerintah untuk melakukan penyimpangan penggunaan anggaran. Kondisi tersebut dapat menimbulkan resiko tuntutan hukum terhadap aparatur pemerintah yang melaksanakan pengelolaan keuangan.

Dalam pelaksanaan pengelolaan keuangan pemerintah, audit intern atau pengawasan intern pemerintah pusat maupun daerah dilaksanakan oleh Aparat Pengawasan Intern Pemerintah (APIP). Inspektorat merupakan bagian dari APIP yang memiliki tugas pokok dan fungsi pengawasan terhadap penyelenggaraan pemerintah.

Kualitas audit yang dilaksanakan oleh aparat Inspektorat hingga saat ini masih menjadi sorotan. Dalam beberapa kasus, aparat inspektorat sebagai 
internal auditor tidak mendeteksi adanya temuan audit akan tetapi Badan Pemeriksa Keuangan (BPK) sebagai eksternal audit dapat mendeteksi temuan. Menurut Ikhtisar Hasil Pemeriksaan (IHP) Badan Pemeriksa Keuangan (BPK) Semester II Tahun 2011, dari 516 Laporan Keuangan Daerah (LKPD) tahun 2010 yang telah selesai diperiksa, hanya 32 entitas yang memperoleh opini Wajar Tanpa Pengecualian, 341 entitas memperoleh opini Wajar Dengan Pengecualian (WDP), 26 entitas memperoleh opini Tidak Wajar (TW) dan 115 entitas memperoleh opini Tidak Memberikan Pendapat (TMP).

Rendahnya kualitas audit pada Inspektorat dapat disebabkan oleh beberapa fenomena sebagai berikut :

- Minimnya pendidikan dan pelatihan fungsional di bidang pengawasan secara berkelanjutan.

- Intervensi dan pengaruh dari penentu kebijakan, hubungan kekeluargaan / kekerabatan dan pertemanan dengan auditi.

- Kode etik bagian tak terpisahkan dari standar audit tidak dijalankan dengan benar dan konsisten, sehingga kasus-kasus penyimpangan kerap terjadi.

- Lingkungan kerja yang tidak kondusif yang disebabkan seringnya terjadi mutasi dan tidak tersedianya program insentif bagi pegawai yang berprestasi.

Audit yang berkualitas salah satu tujuan akhir dari proses audit, audit yang berkualitas dapat dilihat dari tingkat kepatuhan auditor terhadap prosedur dan ketentuan yang seharusnya dilakukan pada saat melaksanakan audit. Menurut Standar Profesional Akuntan Publik (SPAP, 2001) dengan menerapkan standar auditing dalam melakukan audit, auditor dapat memberikan jaminan terhadap kualaitas audit yang dihasilkan dengan mutu tinggi. Standar auditing ini mencakup mutu professional (professional qualities) auditor independen, pertimbangan (judgment) yang digunakan dalam pelaksanaan audit dan penyusunan laporan auditor.

Menurut Peraturan Menteri Negara Pendayagunaan Aparatur Negara No. PER/o5/M.PAN/03/2008 tanggal 31 Maret 2008 Auditor harus mempunyai pengetahuan, keterampilan dan kompetensi lainnya yang diperlukan dalam melaksanakan tanggung jawabnya. Selanjutnya dijelaskan bahwa auditor APIP harus mempunyai tingkat pendidikan formal minimal Strata Satu (S-1) atau yang setara, disamping itu auditor harus memliliki kompetensi teknis antara lain auditing, akuntansi, administrasi pemerintahan dan komunikasi. Kompetensi dan independensi merupakan standar yang harus dipenuhi oleh seorang auditor untuk dapat melakukan audit dengan baik untuk menghasilkan audit yang berkualitas. Disamping itu kepatuhan pada kode etik sangat diperlukan oleh auditor dalam melaksanakan audit, sebagaimana dinyatakan dalam Peraturan Menteri Negara Pendayagunaan Aparatur Negara No. PER/05/M.PAN/03/2008 tanggal 31 Maret 2008, bahwa auditor wajib mematuhi kode etik yang merupakan bagian yang tidak terpisahkan dari standar audit APIP. Dengan terpenuhinya kriteria tersebut diatas, belum tentu auditor yang memiliki kriteria tersebut akan memiliki komitmen untuk melakukan audit dengan baik. 
Sebagaimana dikatakan oleh Goleman (2001), dengan adanya motivasi maka seseorang akan mempunyai semangat juang yang tinggi untuk meraih tujuan dan memenuhi standar yang ada. Motivasi akan mendorong seseorang, termasuk auditor untuk berprestasi dan menghasilkan audit yang berkuliatas.

\section{TINJAUAN PUSTAKA}

\section{Kualitas Audit}

Kualitas audit menurut Peraturan Menteri Negara Pendayagunaan Aparatur Negara No. PER/o5/M.PAN/o3/2008 tanggal 31 Maret 2008 adalah audit yang melaksanakan tugas pokok dan fungsi (tupoksi) yang dapat mempresentasikan paraktik audit yang seharusnya, menyediakan kerangka kerja pelaksanaan kegiatan audit, melaksanakan perencanaan, koordinasi dan penilaian efektifitas tindak lanjut audit, konsistensi laporan audit, dan berkewajiban mengikuti mengikuti standar audit yang betujuan agar pekerjaan auditor dapat dievaluasi.

\section{Kompetensi}

Menurut Peraturan Menteri Negara Pendayagunaan Aparatur Negara No. PER/o5/M.PAN/03/2008, tanggal 31 Maret 2008, Auditor harus mempunyai pengetahuan, keterampilan dan kompetensi lainnya yang diperlukan dalam melaksanakan tanggung jawabnya. Selanjutnya dijelaskan bahwa auditor APIP harus mempunyai tingkat pendidikan formal minimal Strata Satu (S-1) atau yang setara, disamping itu auditor juga memliliki kompetensi teknis atantara lain auditing, akuntansi, administrasi pemerintahan dan komunikasi. keahlian dan pelatihan teknis yang cukup sebagai auditor.

\section{Independensi}

Menurut Peraturan Menteri Negara Pendayagunaan Aparatur Negara No. PER/o5/M.PAN/03/2008 tanggal 31 Maret 2008 Auditor harus memiliki sikap netral dan tidak bias serta menghindari konflik kepentingan dalam merencanakan dan melaporkan pekerjaan yang dilakukannya. Disamping itu jika independensi atau obyektifitasnya terganggu, baik secara faktual maupun penampilan, maka gangguan tersebut harus dilaporkan kepada pimpinan APIP.

\section{Kepatuhan pada Kode Etik}

Dalam Peraturan Menteri Negara Pendayagunaan Aparatur Negara nomor PER/O5/M.PAN/03/2008, menyatakan pelaksanaan audit harus mengacu kepada standar audit, dan auditor wajib mematuhi kode etik yang merupakan bagian yang tak terpisahkan dari standar audit. Selanjutnya menurut Peraturan Menteri Dalam Negeri No. 28 Tahun 2007 Lampiran II, Kode etik dibuat bertujuan untuk mengatur hubungan antara, lembaga dan organisasinya, sesama pejabat pengawas pemerintah, pihak yang diawasi, pihak lain yang terkait dan masyarakat. 


\section{Motivasi}

Pengertian motivasi menurut Goleman (2001), hanya motivasi yang akan membuat seseorang mempunyai semangat juang yang tinggi untuk meraih tujuan dan memenuhi standar yang ada. Motivasi menurut Fred Luthans (2006) adalah proses yang dimulai dengan defisiensi fisiologis atau psikologis yang menggerakkan perilaku atau dorongan yang ditujukan untuk tujuan atau insentif. Perilaku seseorang pada hakikatnya ditentukan oleh motivasi atau keinginan.

\section{KERANGKA PEMIKIRAN DAN HIPOTESIS}

Beberapa penelitian tentang kualitas audit yang pernah dilakukan menyimpulkan temuan yang berbeda mengenai faktor yang mempengaruhi kualitas audit. Hasil penelitian Alim dkk. (2007) dan Elfarini (2007), menyimpulkan bahwa keahlian dan independensi auditor berpengaruh positif terhadap kualitas audit. Penelitian Lubis (2009) menemukan bahwa kepatuhan pada kode etik berpengaruh positif terhadap kualitas audit. Selanjutnya Efendy (2010) menyimpulkan motivasi berpengaruh positif dan signifikan terhadap kualitas audit.

\section{Hipotesis Penelitian}

Berdasarkan telaah teoritis, hasil-hasil penelitian terdahulu, serta kerangka pemikiran teoritis tentang faktor-faktor yang berpengaruh terhadap kualitas audit yang dilaksanakan oleh auditor internal, maka dikembangkan hipotesis dengan penjelasan sebagai berikut :

\section{Pengaruh kompetensi terhadap kualitas audit aparat Inspektorat}

Kualitas audit merupakan kemungkinan auditor menemukan serta melaporkan pelanggaran pada sistem akuntansi pemerintah dengan berpedoman pada standar akuntansi dan standar audit yang telah ditetapkan. Definisi kualitas audit menurut De Angelo (1981) adalah sebagai probabilitas bahwa auditor akan menemukan dan melaporkan pelanggaran pada sistem akuntansi klien.

Penelitian tentang kulitas audit dilakukan Alim dkk (2007), penelitian dilakukan pada kantor Akuntan Publik se-Jawa Timur. Dalam penelitiannya varibel yang digunakan adalah kompetensi dan independensi sebagai variabel independen, kualitas audit sebagai variabel dependen, dan etika auditor sebagai variabel moderasi. Penelitian tersebut menyimpulkan bahwa kompetensi auditor berpengaruh signifikan terhadap kualitas audit. Dengan demikian, dapat dikemukakan hipotesis sebagai berikut: $\mathrm{H} 1$ : Kompetensi berpengaruh signifikan terhadap kualitas audit aparat Inspektorat.

\section{Pengaruh independensi terhadap kualitas audit aparat Inspektorat.}

Independensi adalah sikap auditor yang tidak memihak, tidak mempunyai kepentingan pribadi, dan tidak mudah dipengaruhi oleh pihak-pihak yang berkepentingan dalam memberikan pendapat atau kesimpulan, sehingga pendapat atau simpulan yang diberikan berdasarkan integritas dan objektivitas yang tinggi. 
Holmes dalam Supriyono (1988), menyatakan bahwa independensi merupakan sikap bebas dari bujukan, pengaruh, atau pengendalian pihak yang diperiksa. Independensi auditor merupakan salah satu faktor penting dalam menghasilkan audit yang berkulitas. Selanjutnya penelitian yang dilakukan Alim dkk (2007) menyimpulkan bahwa independensi auditor berpengaruh signifikan terhadap kualitas audit. Dengan demikian, dapat dikemukakan hipotesis sebagai berikut : H2 : Independensi berpengaruh signifikan terhadap kualitas audit aparat Inspektorat.

\section{Pengaruh kepatuhan pada kode etik terhadap kualitas audit aparat Inspektorat.}

Peraturan Menteri Negara Pendayagunaan Aparatur Negara nomor PER/O5/M.PAN/03/2008, menyatakan pelaksanaan audit harus mengacu kepada standar audit, dan auditor wajib memetuhi kode etik yang merupakan bagian yang tak terpisahkan dari standar audit. Auditor harus mematuhi Kode Etik yang ditetapkan. Selanjutnya Peraturan Menteri Dalam Negeri No. 28 Tahun 2007 Lampiran II, menyatakan Kode etik dibuat bertujuan untuk mengatur hubungan antara, lembaga dan organisasinya, sesama pejabat pengawas pemerintah, pihak yang diawasi, pihak lain yang terkait dan masyarakat.

Lubis (2009) dalam penelitiannya menyimpulkan kepatuhan pada kode etik berpengaruh signifikan terhadap kualitas auditor Inspektorat. Dengan demikian, dapat dikemukakan hipotesis sebagai berikut: $\mathrm{H}_{3}$ : Kepatuhan pada kode etik berpengaruh signifikan terhadap kualitas audit aparat Inspektorat.

\section{Pengaruh motivasi terhadap kualitas audit aparat Inspektorat}

Sebagaimana dikatakan oleh Goleman (2001), hanya motivasi yang akan membuat seseorang mempunyai semangat juang yang tinggi untuk meraih tujuan dan memenuhi standar yang ada. Dengan kata lain, motivasi akan mendorong seseorang, termasuk auditor, untuk berprestasi, komitmen terhadap kelompok serta memiliki inisiatif dan optimisme yang tinggi.

Efendy (2010) dalam penelitiannya menyatakan motivasi berpengaruh positif dan signifikan terhadap kualitas audit. Dengan demikian, dapat dikemukakan hipotesis sebagai berikut: $\mathrm{H}_{4}$ : $\quad$ Motivasi berpengaruh positif dan signifikan terhadap kualitas audit aparat Inspektorat.

\section{METODOLOGI}

\section{Populasi dan Sampel}

Populasi dalam penelitian ini adalah seluruh auditor Inspektorat pada 9 (sembilan) kabupaten / kota di Provinsi Riau dengan jumlah sebanyak 148 orang. Dalam penelitian ini seluruh elemen populasi dijadikan sebagai sampel.

\section{Pengambilan Data}


Teknik pengumpulan data dalam penelitian ini dengan menggunakan kuesioner, seperti yang dikemukakan oleh Sugiyono (1999), kuesioner merupakan teknik pengumpulan data yang dilakukan dengan cara memberi seperangkat pertanyaan atau pernyataan tertulis kepada responden untuk dijawab. Dalam penelitian ini yang akan diberikan kuesioner adalah Auditor Inspektoratse - Provinsi Riau yang berjumlah 148 orang.

\section{Definisi dan Pengukuran Variabel}

Dalam penelitian ini, variabel dependen ( $\mathrm{Y}$ ) yang digunakan adalah kualitas audit inspektorat, sedangkan variabel independennya terdiri dari kompetensi (X1), independensi (X2), kepatuhan pada kode etik (X3) dan motivasi (X4). Definisi operasional dan pengukuran untuk variabel-variabel tersebut adalah sebagai berikut :

\section{Kualitas audit}

Kualitas audit adalah, audit yang melaksanakan tugas pokok dan fungsi (tupoksi) yang dapat mempresentasikan paraktik audit yang seharusnya, menyediakan kerangka kerja pelaksanaan kegiatan audit, melaksanakan perencanaan, koordinasi dan penilaian efektifitas tindak lanjut audit, konsistensi laporan audit, dan berkewajiban mengikuti mengikuti standar audit yang betujuan agar pekerjaan auditor dapat dievaluasi (Peraturan Menteri Negara Pendayagunaan Aparatur Negara nomor PER/o5/M.PAN/03/2008).

\section{Kompetensi auditor}

Kompetensi auditor adalah Auditor yang memiliki pengetahuan, keterampilan dan kompetensi lainnya yang diperlukan dalam melaksanakan tanggunggung jawabnya. Disamping itu auditor harus mempunyai tingkat pendidikan formal minimal Strata Satu (S-1) atau yang setara, auditor harus memliliki kompetensi teknis antara lain auditing, akuntansi, administrasi pemerintahan dan komunikasi, keahlian dan pelatihan teknis yang cukup sebagai auditor (Peraturan Menteri Negara dan Pendayagunaan Aparatur Negara No. PER/o5/M.PAN/o3/2008 tanggal 31 Maret 2008).

\section{Independensi auditor}

Independensi adalah sikap netral dan tidak bias serta menghindari konflik kepentingan dalam merencanakan dan melaporkan pekerjaan yang dilakukan. Disamping itu jika independensi atau obyektifitasnya terganggu, maka gangguan tersebut harus dilaporkan kepada pimpinan APIP (Peraturan Menteri Negara dan Pendayagunaan Aparatur Negara No. Per/05/M.Pan/o3/2008 tanggal 31 Maret 2008).

\section{Kepatuhan auditor pada kode etik}

Pelaksanaan audit harus mengacu kepada standar audit, dan auditor harus mematuhi kode etik yang merupakan bagian yang tidak terpisahkan dari standar audit. Kode etik pejabat pengawas pemerintah dimaksudkan untuk memberikan pengertian dan penjabaran mengenai aturan perilaku sebagai pejabat pengawas pemerintah yang profesional dan sebagai pedoman bagi pejabat pengawas 
pemerintah dalam berhubungan dengan : lembaga dan organisasinya, sesama pejabat pengawas pemerintah, pihak yang diawasi, pihak lain yang terkait dan masyarakat (Peraturan Menteri Dalam Negeri No. 28 Tahun 2007 Lampiran II).

\section{Motivasi}

Motivasi dalam pelaksnaan audit sebagai ukuran seberapa besar dorongan yang dimiliki auditor untuk melaksanakan audit yang berkualitas. Sebagaimana dikatakan oleh Goleman (2001), hanya motivasi yang akan membuat seseorang mempunyai semangat juang yang tinggi untuk meraih tujuan dan memenuhi standar yang ada. Dengan kata lain, motivasi akan mendorong seseorang, termasuk auditor, untuk berprestasi, komitmen terhadap kelompok serta memiliki inisiatif dan optimisme yang tinggi. Respon atau tindak lanjut yang tidak tepat terhadap laporan audit dan rekomendasi yang dihasilkan akan dapat menurunkan motivasi aparat untuk menjaga kualitas audit.

\section{Instrumen Penelitian}

Instrumen penelitian yang merupakan media dalam pengumpulan data, menggunakan kuesioner. Kuesioner penelitian ini mengadopsi dari penelitian Lubis (2010), tetapi perbaikan / penyesuaian terhadap butir-butir pertanyaan dilakukan berdasarkan Peraturan Menteri Negara Pendayagunaan Aparatur Negara No. PER/o5/M-PAN/03/2008 tanggal 31 Maret 2008 tentang Standar Audit Aparat Pengawasan Intern Pemerintah (APIP), Standar Pemeriksaan Keuangan Negara dan Peraturan Menteri Dalam Negeri No. 28 Tahun 2007 tanggal 30 Maret 2007 tentang Norma Pengawasan dan Kode Etik Pejabat Pengawas Pemerintah.

\section{HASIL PENELITIAN DAN PEMBAHASAN}

\section{Uji Validitas}

Uji validitas adalah untuk mengetahui sah tidaknya instrumen kuisioner yang digunakan dalam pengumpulan data. Uji validitas ini dilakukan untuk mengetahui apakah item-item yang tersaji dalam kuesioner benar-benar mampu mengungkapkan dengan pasti apa yang akan diteliti (Ghozali, 2006). Uji validitas dilakukan dengan uji korelasi Corrected Item Total Correlation antara masingmasing skor indikator dengan total skor konstruk. Suatu butir pertanyaan dikatakan valid jika nilai korelasi item butir dengan skor total signifikan apabila nilai corrected item total correlationnya $>0.3$.

Hasil uji validitas diketahui bahwa semua item kuesioner yang akan digunakan untuk mengumpulkan data dinyatakan telah valid seluruhnya. Hal ini dikarenakan nilai corrected item total correlation telah $>0,3$. Artinya keseluruhan item pertanyaan kuesioner dapat digunakan dalam penelitian ini.

\section{Uji Reliabilitas}

Suatu kuesioner dikatakan handal atau reliabel jika jawaban seseorang terhadap pertanyaan adalah konsisten atau stabil dari waktu ke waktu. Uji Reliabilitas dimaksudkan untuk menguji konsistensi kuesioner dalam mengukur 
suatu konstruk yang sama atau stabilitas kuesioner jika digunakan dari waktu ke waktu (Ghozali, 2006). Uji reliabilitas dilakukan dengan metode internal consistency. Kriteria yang digunakan dalam uji ini adalah One Shot, artinya satu kali pengukuran saja dan kemudian hasilnya dibandingkan dengan pertanyaan lainnya atau dengan kata lain mengukur korelasi antar jawaban pertanyaan. Statistical Product and Service Solution (SPSS) memberikan fasilitas untuk mengukur reliabilitas dengan uji statistik Cronbach Alpha (a). Jika nilai koefisien alpha lebih besar dari o,60 maka disimpulkan bahwa intrumen penelitian tersebut handal atau reliabel (Nunnaly dalam Ghozali, 2006).

Hasil pengujian diperoleh reliabilitas bahwa variabel kompetensi $\left(\mathrm{x}_{1}\right)$ independensi $\left(\mathrm{x}_{2}\right)$ kepatuhan pada kode etik $\left(\mathrm{x}_{3}\right)$ motivasi $\left(\mathrm{x}_{4}\right)$ dan kualitas audit(y) telah bersifat reliabel, dikarenakan nilai Alpha Cronbach's $>$ o.6.

Hasil uji validitas dan realibilitas menunjukkan data penelitian telah valid dan realible. Oleh karena itu data Penelitian sudah bisa dapat digunakan dalam penelitian ini. Data kuesioner merupakan data berskala Ordinal, dimana skala ordinal tidak dapat diinput kedalam SPSS guna diolah. Oleh Karena itu data berskala ordinal harus diubah dahulu kedalam bentuk Interval menggunakan program MSI (Methode Succesive Interval).

Uji normalitas bertujuan untuk menguji apakah variabel terikat dan variabel bebas dalam model regresi mempunyai distribusi normal atau tidak. Hasil pengujian normalitas menunjukkan grafik normal plot model regeresi I dan model regeresi II terlihat titik-titik menyebar disekitar diagonal serta penyebarannya mengikuti arah garis diagonal dan grafik normal plot tersebut membentuk garis lurus dari sisi kiri bawah kekanan atas sesuai dengan teori linearitas, sehingga dapat disimpulkan bahwa linearitas dalam model regresi ini sudah dipenuhi.

\section{Pengaruh kompetensi terhadap kualitas audit aparat Ispektorat.}

Hasil menunjukkan bahwa terdapat pengaruh Kompetensi terhadap kualitas audit, dimana nilai $t_{\text {hitung }}$ sebesar 2.522 dengan nilai signifikansi 0.013 serta $\mathrm{t}_{\text {tabel }} \alpha ; \mathrm{n}-p(0.05 ; 108)$ sebesar 1.98. Karena nilai $\mathrm{t}_{\text {hitung }} 2.522>\mathrm{t}_{\text {tabel }} 1.98$, dengan signifikansi $0.013<0.05$ dapat disimpulkan Ha diterimat, secara perhitungan statistik dapat disimpulkan bahwa kompetensi berpengaruh signifikan terhadap kualiatas audit aparat inspektorat, dengan demikian dapat diartikan semakin tinggi kompetensi yang dimiliki auditor akan meningkatkan kualitas audit.

\section{Pengaruh Independensi terhadap Kualitas Audit}

Hasil penelitian ini menunjukkan bahwa terdapat pengaruh Independensi terhadap kualitas audit, dengan nilai $\mathrm{t}_{\text {hitung }}$ sebesar 2.203 dengan nilai signifikansi 0.030 serta $\mathrm{t}_{\text {tabel }} \alpha ; \mathrm{n}-p(0.05 ; 108)$ sebesar 1.98. Karena nilai $\mathrm{t}_{\text {hitung }} 2.203>\mathrm{t}_{\text {tabel }}$ 1.98, dengan signifikansi $0.030<0.05$ dapat disimpulkan Ha diterima. Dengan demikian dapat diartikan semakin tinggi independensi yang dimiliki auditor akan meningkatkan kualias audit yang dihasilkan, secara perhitungan statistik dapat 
disimpulkan bahwa independensi berpengaruh signifikan terhadap kulitas audit aparat inspektorat. 


\section{Pengaruh Kepatuhan pada kode etik terhadap Kualitas Audit}

Hasil penelitian ini menunjukkan bahwa terdapat pengaruh Kepatuhan Pada Kode Etik terhadap kualitas audit, dengan nilai $t_{\text {hitung }}$ sebesar 11.101 dengan nilai signifikansi 0.000 serta $t_{\text {tabel }} \alpha ; \mathrm{n}-p(0.05 ; 108)$ sebesar 1.98. Karena nilai $\mathrm{t}_{\text {hitung }} 11.101>\mathrm{t}_{\text {tabel }} 1.98$, dengan signifikansi $0.000<0.05$ dapat disimpulkan Ha diterima. Dengan demikian dapat diartikan bahwa semakin tinggi tingkat kepatuhan auditor terhadap kode etik akan meningkatkan kualitas audit yang dihasilkan. secara perhitungan statistik dapat disimpulkan bahwa kode etik berpengaruh signifikan terhadap kualitas audit aparat inspektorat.

\section{Pengaruh Motivasi terhadap Kualitas Audit}

Hasil penelitian ini menunjukkan bahwa terdapat pengaruh Motivasi terhadap kualitas audit, dengan nilai $t_{\text {hitung }}$ sebesar 2.285 dengan nilai signifikansi 0.024 serta $t_{\text {tabel }} \alpha ; \mathrm{n}-p(0.05 ; 108)$ sebesar 1.98. Karena nilai $t_{\text {hitung }} 2.285>\mathrm{t}_{\text {tabel }}$ 1.98, dengan signifikansi $0.024<0.05$ dapat disimpulkan Ha diterima. Dengan demikian dapat diartikan bahwa semakin tinggi motivasi yang dimiliki auditor akan meningkatkan kulitas audit yang dihasilkan, secara perhitungan statistik dapat disimpulkan bahwa motivasi berpengaruh signifikan terhadap kualitas audit aparat inspektorat.

\section{Uji Simultan.}

Berdasarkan hasil pengujian dengan menggunakan program SPSS, diperoleh $\mathrm{F}_{\text {hitung }}$ sebesar 109.71 dengan nilai probabilitas 0.000, dimana probabilitas lebih kecil dari pada nilai signifikansi 0,05, maka model regresi dapat digunakan untuk memprediksi kualitas audit. Selanjutnya dengan membandingkan nilai $\mathrm{F}_{\text {hitung }}$ nilai $\mathrm{F}_{\text {tabel }}$ dimana apabila $\mathrm{F}_{\text {hitung }}>$ nilai $\mathrm{F}_{\text {tabel }}$ dapat disimpulkan secara simultan variabel-variabel independen berpengaruh signifikan terhadap variabel dependen.

Dengan nilai ( $\alpha$; $d b 1, d b 2$ ) yakni sebesar 2.46 dengan $\mathrm{df}_{1}=4$ (jumlah varibel independen) dan df2 $=108(\mathrm{n}-\mathrm{k}-1)$. sehingga nilai $\mathrm{F}_{\text {hitung }}>\mathrm{F}_{\text {tabel, }}$ dimana (109.71 > 2.46). maka dapat disimpulkan bahwa kompetensi, independensi, kepatuhan pada kode etik, dan motivasi secara bersama-sama (simultan) berpengaruh terhadap kualitas audit

\section{Koefisien determinasi}

Nilai Adjusted R Square sebesar 0.795 (79.50\%), artinya variabel kompetensi, independensi, kepatuhan pada kode etik, dan motivasi dapat menerangkan variable kualitas hasil audit 0.795 atau $79.50 \%$, sedangkan sisanya sebesar 20.50\% lagi diterangkan variable lain yang tidak diteliti dalam penelitian ini. 


\section{PENUTUP}

\section{Kesimpulan.}

Penelitian ini secara empiris menemukan bahwa kompetensi berpengaruh signifikan terhadap kualitas audit dengan demikian dapat diartikan bahwa semakin tinggi tingkat kompetensi yang dimiliki auditor akan semakin tinggi kualitas audit yang dihasilkan. Selanjutnya independensi berpengaruh signifikan terhadap kualitas audit dapat diartikan bahwa semakin tinggi tingkat independensi yang dimiliki auditor maka semakin tinggi kulitas audit yang dihasilkan. Kepatuhan pada kode etik berpengaruh signifikan terhadap kulitas audit dengan demikian dapat diartikan bahwa semakin tinggi kepatuhan auditor terhadap kode etik maka semakin tinggi juga kualitas audit yang dihasilkan. Penelitian ini juga menemukan bahwa motivasi berpengaruh signifikan terhadap kualitas audit, dengan demikian dapat diartikan bahwa semakin tinggi motivasi yang dimiliki auditor akan meningkatkan kualitas audit yang dihasilkan. Sebaliknya apabila kompetensi, independensi dan kepatuhan pada kode etik dan motivasi auditor rendah maka kualitas audit yang dihasilkan juga rendah

Penelitian ini juga menemukan bahwa kompetensi, independensi, kepatuhan pada kode etik dan motivasi secara bersama-sama berpengaruh signifikan terhadap kulaitas audit.

\section{Rekomendasi.}

Menyangkut luasnya cakupan penelitian, penelitian berikutnya dapat menambah sampel yang diteliti dan memperluas penelitian pada aparat Inspektorat se-Sumatera atau se-Indonesia, sehingga diharapkan tingkat generalisasi dari analisis semakin akurat. Disamping itu dalam menentukan kualitas audit, masih dipengaruhi faktor-faktor lain yang dapat dipakai pada penelitan berikutnya dalam mengukur kualitas audit, misalnya faktor komitmen, faktor penggunaan Teknolgi Informatika (TI), faktor jangka waktu pelaksanaan audit, faktor loyalitas, faktor audit program dan faktor reward. Penelitian ini menggunakan data primer, peneliti berikutnya dapat manggunakan data sekunder.

\section{DAFTAR PUSTAKA}

Abdul Halim. 2008. Akuntansi Sektor Publik, Akuntansi Keuangan Daerah, Edisi 3. Jakarta. Salemba Empat.

Alim, M.N., T. Hapsari, dan L. Purwanti. 2007. Pengaruh Kompetensi danIndependensi terhadap Kualitas Audit dengan Etika Auditor sebagai VariabelModerasi. Simposium Nasional Akuntansi X. Makassar.

Arens, Alvin A., and J.K. Loebecke, 1996, Auditing : Pendekatan Terpadu, Adaptasi oleh Amir Abadi Yusuf, Buku Satu. Jakarta. Salemba Empat,

Badan Pemeriksa Keuangan Republik Indonesia. Ihtisar Hasil Pemeriksaan Sementara, Semester II Tahun 2011. 
BPKP. 1998. Modul Diklat Peningkatan Kemampuan APFP Provinsi DI Yogyakarta. Yogyakarta. Unit Pengelola Pendidikan dan Latihan Pengawasan Perwakilan BPKP DI Yogyakarta.

BPKP. 2008. Kode Etik dan Standard Audit. Pusat Pendidikan dan Pelatihan BPKP, Edisi Kelima.

Firdaus, 2005. Auditing, Pendekatan Pemahaman Secara Konprehensif. Yogyakarta. Graha Ilmu,.

Ghozali, I., 2006. Aplikasi Analisis Multivariat dengan Program SPSS. Edisi 3. Semarang. BP Undip.

Goleman, D., 2001. Working White Emotional intelligence (terjemahan Alex Tri Kantjono W). Jakarta : PT Gramedia Pustaka Utama

Lubis, Haslinda., 2009. Pengaruh keahlian, independensi, kecermatan profesional dan kepatuhan pada kode etik terhadap kualitas auditor pada Inspektorat Provinsi Sumatera Utara. Tesis. Universitas Sumatera Utara.

Ikatan Akuntan Indonesia., 2001. Standar Profesional Akuntan Publik, Jakarta, Salemba Empat.

Luthans, Fred. 2006. Perilaku organisasi. Yogyakarta : Andi

Mardiasmo. 2006. Pewujudan Transparansi dan Akuntabilitas Publik Melalui Akuntansi Sektor Publik: Suatu Sarana Good Governance. Jurnal Akuntansi Pemerintah 2 (1)

Mardiasmo. 2009. Akuntansi Sektor Publik Edisi 2. Yogyakarta. Penerbit Andi.

Mayangsari, S. 2003. Pengaruh Keahlian Audit dan Independensi terhadap Pendapat Audit: Suatu Kuasieksperimen. Jurnal Riset Akuntansi Indonesia 6 (1) Januari

Messier, F.W., V.S. Glover, dan F.D. Prawitt., 2005. Jasa Audit dan Assurance: Suatu Pendekatan Sistematis. Diterjemahkan oleh Nuri Hinduan. Edisi 4 Buku 1 \& 2. Jakarta. Penerbit Salemba Empat.

Moekijat. 2002. Dasar-Dasar Motivasi. Jakarta. Pioner Jaya,

Muh. Taufiq Efendy, 2010. Pengaruh Kompetensi Independensi Dan Motivasi Terhadap Kualitas Audit Aparat Inspektorat Dalam Pengawasan Keuangan Daerah. Tesis. Semarang. Universitas Diponogoro.

Mulyadi. 1992. Pemeriksaan Akuntan. Yogyakarta.Badan Penerbit STIE YKPN.

Peraturan Menteri Dalam Negeri No 64 Tahun 2007. Pedoman Teknis Organisasi dan Tata Kerja Inpektorat Propinsi dan Kabupaten/Kota.

Peraturan Menteri Dalam Negeri No. 4 Tahun 2008. Pedoman Pelaksanaan Reviu Atas Laporan Keuangan Daerah.

Peraturan Menteri Dalam Negeri Nomor 28 Tahun 2007. Norma Pengawasan dan Kode Etik Pejabat Pengawas Pemerintah.

Peraturan Menteri Negara Pendayagunaan Aparatur Negara nomor PER/05/M.PAN/03/2008. Standar Audit Aparat Pengawasan Intern Pemerintah. Jakarta.

Peraturan Pemerintah No. 41 Tahun 2007 Tentang Organisasi Perangkat Daerah. 
Peraturan Pemerintah No. 79 tahun 2005. Pedoman Pembinaan dan Pengawasan Penyelenggaraan Pemerintahan Daerah.

Peraturan Pemerintah No. 8 Tahun 2006. Pelaporan Keuangan dan Kinerja Instansi Pemerintah.

Robbins, S.P., dan T.A. Judge, 2008. Perilaku Organisasi, edisi 12. Jakarta. Salemba Empat.

Samelson, D., Lowenshon, S., dan Johnson, L., 2006. The Determinants of Perceived Audit Quality and Auditee Satisfaction in Local Government. Journal of Public Budgeting, Accounting, \& Financial Management 18(2)

Sri Lastanti, Hexana, 2005. Tinjauan Terhadap Kompetensi dan Independensi Akuntan Publik : Refleksi Atas Skandal Keuangan. Media Riset Akuntansi, Auditing dan Informasi 5 (1) April

Sugiyono, 2008. Metode Penelitian Kuantitatif, Kualitatif, dan R\&D. Bandung. Penerbit Alfabeta.

Supriyono, R.A., 1988. Pemeriksaan Akuntan (Auditing) Faktor-faktor yang Mempengaruhi Independensi Penampilan Akuntan Publik. Yogyakarta. Penerbit BPFE.

Umar, Husein, (2000). Riset \& Pemasaran Perilaku Konsumen. Jakarta. Penerbit PT Gramedia. 